\title{
Association of IL4, IL6, and IL10 polymorphisms with pulmonary tuberculosis in a Tibetan Chinese population
}

\author{
Shumei $\mathrm{He}^{1,2,3, *}$, Shenglai Yang ${ }^{4, *}$, Qin Zhao ${ }^{1,2,3}$, Liang Wang ${ }^{1,2,3}$, Hang Liu ${ }^{1,2,3}$, \\ Yemeng Sheng ${ }^{1,2,3}$, Dongya Yuan ${ }^{1,2,3}$ and Tianbo Jin ${ }^{1,2,3,5}$ \\ ${ }^{1}$ Key Laboratory for Molecular Genetic Mechanisms and Intervention Research on High Altitude Disease of Tibet Autonomous \\ Region, School of Medicine, Xizang Minzu University, Xianyang, Shaanxi 712082, China \\ ${ }^{2}$ Key Laboratory for Basic Life Science Research of Tibet Autonomous Region, School of Medicine, Xizang Minzu University, \\ Xianyang, Shaanxi 712082, China \\ ${ }^{3}$ Key Laboratory of High Altitude Environment and Gene Related to Disease of Tibet Ministry of Education, School of Medicine, \\ Xizang Minzu University, Xianyang 712082, Shaanxi, China \\ ${ }^{4}$ Shaanxi Normal University, Xi'an, Shaanxi 710062, China \\ ${ }^{5}$ Key Laboratory of Resource Biology and Biotechnology in Western China (Northwest University), Ministry of Education, Northwest \\ University, Xi'an 710069, China \\ *Joint first authors \\ Correspondence to: Tianbo Jin, email: jintianbo@gmail.com \\ Dongya Yuan, email: dongyayuan163@163.com \\ Keywords: pulmonary tuberculosis; IL4; IL6; IL 10; Tibetan Chinese population \\ Received: June 21,2017 Accepted: November 11,2017 Epub: January 06, 2018 Published: March 27, 2018
}

Copyright: $\mathrm{He}$ et al. This is an open-access article distributed under the terms of the Creative Commons Attribution License 3.0 (CC BY 3.0), which permits unrestricted use, distribution, and reproduction in any medium, provided the original author and source are credited.

\section{ABSTRACT}

Background: Pulmonary tuberculosis (PTB) is an infectious disease with a high incidence worldwide. Genes encoding cytokines IL4, IL6, and IL10 are highly polymorphic and can influence the susceptibility to PTB.

Results: We found correlations between one SNP in IL6 (rs2069837 $p=6.63 \mathrm{E}-11)$, seven SNPs in IL10 (rs1554286 $p=6.87 \mathrm{E}-20$, rs1518111 $p=6.11 \mathrm{E}-11$, rs3021094 $p=6.75 \mathrm{E}-29$, rs3790622 $p=2.40 \mathrm{E}-06$, rs3024490 $p=6.73 \mathrm{E}-11$, rs1800872 $p=6.18 \mathrm{E}-11, \mathrm{rs} 1800871 p=6.73 \mathrm{E}-11)$ and incidences of PTB. The SNPs rs2069837, rs1554286, rs1518111, rs3024490, rs1800872, and rs1800871 increased PTB risk by 1.95-fold, 2.34-fold, 1.84-fold, 1.84-fold, 1.84-fold and 1.84-fold, respectively. The SNPs rs3021094 and rs3790622 decreased PTB risk by 0.33-fold and 0.38-fold, respectively. We also found two linkage disequilibrium blocks in the studied $I L$ SNPs. The IL4 haplotype TCCCGGA (OR $=1.33, p=0.014)$ increased PTB risk, the $I L 10$ haplotypes ATGGATA $(O R=0.39, p=4.84 \mathrm{E}-06)$ provided a protective effect and decreased PTB risk.

Materials and Methods: For this study, we recruited 467 subjects with PTB and 503 healthy subjects from a Tibetan population living in Lhasa and nearby, China. Association analyses of sixteen single-nucleotide polymorphisms (SNPs) in IL4, IL6, and $I L 10$ were performed.

Conclusions: Our findings demonstrate an association between polymorphisms in IL6 and IL10 and risk of PTB.

\section{INTRODUCTION}

Pulmonary tuberculosis (PTB) is caused by Mycobacterium tuberculosis (M. tuberculosis) and is one of the leading causes of death worldwide. Since 1980, the incidences of PTB and mortality rates have increased rapidly [1]. Tuberculosis in 2009 global statistics show that about 9.4 million people are infected with tuberculosis, 1.7 million people died of tuberculosis [2]. The incidence of PTB in Asian countries accounts for $60 \%$ of the total infections worldwide. The number of PTB patients in China is the second largest in the world, and China is 
considered as one of the 22 high-burden countries. Tibet is one of the regions with high TB burden. The statistical analysis of the tuberculosis epidemic situation in the Tibet Autonomous Region in 2011-2013 showed that the number of cases and incidence of tuberculosis in Tibet Autonomous Region was 4046 and 134.9/100,000, 4096 and 136.5/100,000, 4273 and 142.4/100,000, respectively. Although $M$. tuberculosis has infected almost one-third of the population worldwide, only $10 \%$ of patients produce corresponding clinical symptoms during their lifetime [3], implicating that additional factors may influence the incidence of disease among different individuals.

Previous studies have identified genes that confer disease susceptibility by regulating the immune response $[4,5]$. A twin study found that PTB concordance in identical twins is 2-fold higher than in non-identical twins [6]. Thus, we expect that identification of host genetic factors for PTB susceptibility may play a key role in PTB control worldwide. The first published tuberculosis GWAS identified chr18q11 rs4331426 as the susceptible loci for tuberculosis [7]. After that, in Garner, Gambia, Indonesia, and Russia, rs2057178, located on the chr11q3 downstream of the WT1 gene, was identified as a resistance gene loci [8]. In a recent GWAS study published in the Russian population, the ASAP1 gene intron SNP (rs4733781, rs 10956514) located on the 8q24 chromosome was associated with tuberculosis [9]. In the Chinese population validation study found that the results differ from those of other ethnic groups. In recent years, more and more research has been done on the susceptibility to tuberculosis in the world. Linkage analysis and candidate gene association studies identified a number of possible susceptibility genes for tuberculosis, which can be divided into human leukocyte associated antigen genes and non HLA genes. Non HLA genes include $V D R, M B L, T L R$, P2X, IL4, IL6, IL 10, and so on [10-14].

Interleukin-4 $(I L-4)$, is located on chromosome 5q31.1, an anti-inflammatory cytokine has been implicated to down-regulate IFN- $\gamma$, and thus has a deleterious effect on TB patients $[13,15]$. One research found that IL4 variant rs2070874 showed a two-fold risk by $\mathrm{T}$ allele in north Indians $(\mathrm{OR}=1.8, p=0.01)$ [13]. In Iranians, $I L-4-590$ (rs2243250) $\mathrm{C}$ allele and the TC genotypes were found to be significantly more common in TB patients than in controls, and the -1098 (rs2243248) and -33 (rs2070874) were not found to be associated with susceptibility to TB [16]. Qi $\mathrm{H}$ et al. [15] investigated the association between susceptibility to TB and singlenucleotide polymorphisms (SNPs) of the $I L-4$ (rs2243250, rs2243268, rs2243274, and rs2243282) and IL-10 genes (rs1800871, rs3021094, and rs3790622) in Chinese population, and found that rs2243268-A and rs2243274-G of the $I L-4$ gene reduced the risk of developing EPTB and severe TB.

$I L-6$ is secreted by Toll-like receptor 2-expressing cells in response to the presence of Mycobacterium tuberculosis early in infection and is involved in antituberculosis immunity in the body [17]. High levels of IL-6 cytokine are produced in response to MTB infection [18], and its role seems especially critical when bacterial burden is high [19]. Rong $H$ et al. [20] shown that rs1524107 CT genotype significantly increased the risk of $\mathrm{TB}$, but the association disappeared after stratified by age and gender.

Interleukin 10 (IL10) is a multifunctional cytokine mainly produced by Th2 cells, the main function of antigen presentation function for stromal macrophages, through down-regulation of inflammatory cytokines, thereby inhibiting macrophage function during inflammation, inhibit Th1 cell response, inhibition of Th1 cells to produce cytokines IFN- $\gamma$, is a kind of cytokines the incidence of tuberculosis, play a role in the pathogenesis of tuberculosis. The study found that IL10 gene associated with the risk of tuberculosis [21]. Studies in Asian population reported the minor allele "G" of rs1800172 in IL10 was associated with a decreased $\mathrm{PTB}$ risk $(\mathrm{OR}=0.69)$ whereas no risk association was found in Europeans $(\mathrm{OR}=1.19)$, Africans $(\mathrm{OR}=1.01)$ [22]. The study of Halstrom $\mathrm{S}$ implicated the minor (A) allele of rs1518111 in risk of pulmonary NTM disease in Caucasians [23].

Through the literature search, we found that interleukin gene is related to the occurrence of tuberculosis, few studies have explored the association between IL4, IL6, and IL10 polymorphisms and PTB risk in Chinese populations. So we selected IL4, IL6, IL10 genes as the study. We combined our previous literature, selected seven IL4 SNPs, two IL6 SNPs, and seven IL10 SNPs to evaluate whether single-nucleotide polymorphisms (SNPs) in the three genes were associated with PTB risk in a Tibetan Chinese population.

\section{RESULTS}

We recruited 467 cases, average age $50.67 \pm 7.80$ years, including 287 female and 180 male; also recruited 503 cases, average age $50.34 \pm 7.74$ years, including 308 female and 195 male. As listed in Table 1, the $p$ value of age $(p=0.686)$ and sex $(p=0.947)$ was more than 0.05 , respectively.

An overview (MAF, OR, 95\% CI, position, HWE, band, alleles, $p$-value) for all candidate SNPs for the study participants was made (Table 2). One SNP rs1524107 $(p=2.79 \mathrm{E}-140)$ was deviated from Hardy-Weinberg Equilibrium $(p<0.05)$ and was excluded in our analysis. Upon investigating the sixteen SNPs in IL4, IL6, and IL10 (Table 2), we found one SNP in IL6 (rs2069837: $\mathrm{OR}=1.95,95 \% \mathrm{CI}=1.60-2.39, p=6.63 \mathrm{E}-11)$ and five SNPs in IL10 (rs1554286: OR $=2.34,95 \% \mathrm{CI}=1.95-$ $2.81, p=6.87 \mathrm{E}-20 ;$ rs $1518111: \mathrm{OR}=1.84,95 \% \mathrm{CI}=$ $1.53-2.22, p=6.11 \mathrm{E}-11 ; \mathrm{rs} 3024490: \mathrm{OR}=1.84,95 \% \mathrm{CI}=$ $1.53-2.21, p=6.73 \mathrm{E}-11 ; \mathrm{rs} 1800872: \mathrm{OR}=1.84,95 \% \mathrm{CI}=$ 
Table 1: Patient demographics

\begin{tabular}{cccc}
\hline Gender & case (467) & control (503) & $p$ \\
\hline female & 287 & 308 & $0.947^{\mathrm{a}}$ \\
male & 180 & 195 & \\
Age, year & $50.67 \pm 7.80$ & $50.34 \pm 7.74$ & $0.686^{\mathrm{b}}$ \\
\hline
\end{tabular}

${ }^{a} p$ values was calculated from Pearson's chi-square tests.

${ }^{\mathrm{b}} p$ values was calculated by Welch's $t$ tests.

$p<0.05$ indicates statistical significance.

Table 2: Summary of basic IL SNP information for all study participants

\begin{tabular}{|c|c|c|c|c|c|c|c|c|c|}
\hline \multirow{2}{*}{ SNP_ID } & \multirow{2}{*}{ Gene } & \multirow{2}{*}{ Band } & \multicolumn{2}{|c|}{ MAF } & \multirow{2}{*}{$\begin{array}{c}\text { Alleles } \\
\text { Aa/B }\end{array}$} & \multirow{2}{*}{ Role } & \multirow{2}{*}{ HWE-p } & \multirow{2}{*}{ OR $(95 \%$ CI $)$} & \multirow{2}{*}{$p$-value } \\
\hline & & & Case & Control & & & & & \\
\hline rs2070874 & IL4 & $5 \mathrm{q} 31.1$ & 0.184 & 0.223 & $\mathrm{C} / \mathrm{T}$ & 5'UTR & 0.093 & $0.79(0.63-0.99)$ & 0.035 \\
\hline rs2227282 & IL4 & $5 \mathrm{q} 31.1$ & 0.150 & 0.166 & $\mathrm{G} / \mathrm{C}$ & Intron & 0.423 & $0.89(0.69-1.13)$ & 0.331 \\
\hline rs2243267 & IL4 & $5 \mathrm{q} 31.1$ & 0.184 & 0.224 & $\mathrm{G} / \mathrm{C}$ & Intron & 0.073 & $0.78(0.62-0.98)$ & 0.031 \\
\hline rs2243268 & IL4 & $5 q 31.1$ & 0.184 & 0.224 & $\mathrm{~A} / \mathrm{C}$ & Intron & 0.073 & $0.78(0.62-0.98)$ & 0.031 \\
\hline rs2243270 & IL4 & $5 \mathrm{q} 31.1$ & 0.184 & 0.224 & $\mathrm{~A} / \mathrm{G}$ & Intron & 0.073 & $0.78(0.62-0.98)$ & 0.031 \\
\hline rs2243288 & IL4 & $5 \mathrm{q} 31.1$ & 0.185 & 0.221 & $\mathrm{~A} / \mathrm{G}$ & Intron & 0.119 & $0.80(0.64-1.01)$ & 0.053 \\
\hline rs2243290 & IL4 & $5 q 31.1$ & 0.183 & 0.217 & $\mathrm{C} / \mathrm{A}$ & Intron (boundary) & 0.089 & $0.81(0.64-1.01)$ & 0.065 \\
\hline rs2069837 & IL6 & $7 \mathrm{p} 15.3$ & 0.345 & 0.213 & $\mathrm{G} / \mathrm{A}$ & Intron & 1 & $1.95(1.60-2.39)$ & $6.63 \mathrm{E}-11^{*}$ \\
\hline rs1524107 & IL6 & $7 \mathrm{p} 15.3$ & 0.225 & 0.427 & $\mathrm{~T} / \mathrm{C}$ & Intron (boundary) & $2.79 \mathrm{E}-140^{\#}$ & $0.39(0.32-0.47)$ & $3.30 \mathrm{E}-21^{*}$ \\
\hline rs 1554286 & IL10 & $1 \mathrm{q} 32.1$ & 0.535 & 0.330 & $\mathrm{G} / \mathrm{A}$ & Intron (boundary) & 0.420 & $2.34(1.95-2.81)$ & $6.87 \mathrm{E}-20^{*}$ \\
\hline rs1518111 & IL10 & $1 \mathrm{q} 32.1$ & 0.473 & 0.328 & $\mathrm{C} / \mathrm{T}$ & Intron (boundary) & 0.156 & $1.84(1.53-2.22)$ & $6.11 \mathrm{E}-11^{*}$ \\
\hline rs3021094 & IL10 & $1 \mathrm{q} 32.1$ & 0.217 & 0.457 & $\mathrm{G} / \mathrm{T}$ & Intron & 0.178 & $0.33(0.27-0.40)$ & $6.75 \mathrm{E}-29^{*}$ \\
\hline rs3790622 & IL 10 & $1 \mathrm{q} 32.1$ & 0.034 & 0.085 & $\mathrm{~A} / \mathrm{G}$ & Intron & 1 & $0.38(0.25-0.58)$ & $2.40 \mathrm{E}-06^{*}$ \\
\hline rs3024490 & IL10 & $1 \mathrm{q} 32.1$ & 0.469 & 0.324 & $\mathrm{C} / \mathrm{A}$ & Intron & 0.309 & $1.84(1.53-2.21)$ & $6.73 \mathrm{E}-11^{*}$ \\
\hline rs 1800872 & IL10 & $1 \mathrm{q} 32.1$ & 0.469 & 0.324 & $\mathrm{G} / \mathrm{T}$ & Promoter & 0.264 & $1.84(1.53-2.22)$ & $6.18 \mathrm{E}-11^{*}$ \\
\hline rs1800871 & IL10 & $1 \mathrm{q} 32.1$ & 0.469 & 0.324 & $\mathrm{G} / \mathrm{A}$ & Promoter & 0.309 & $1.84(1.53-2.21)$ & $6.73 \mathrm{E}-11^{*}$ \\
\hline
\end{tabular}

SNP: single-nucleotide polymorphism; MAF: minor allele frequency; HWE: Hardy-Weinberg equilibrium; OR: odds ratio; $\mathrm{CI}$ : confidence interval; ${ }^{\text {a: }}$ Minor allele.

${ }^{*} p<0.05$ indicates statistical significance.

\#SNP was excluded in the subsequent analysis for deviated from Hardy-Weinberg Equilibrium $(p<0.05)$.

$1.53-2.22, p=6.18 \mathrm{E}-11 ;$ and $\mathrm{rs} 1800871: \mathrm{OR}=1.84,95 \%$ $\mathrm{CI}=1.53-2.21, p=6.73 \mathrm{E}-11)$ that were correlated with increased PTB risk after the Bonferroni correction. We also found two SNPs in IL10 (rs3021094: OR = 0.33, 95\% $\mathrm{CI}=0.27-0.40, p=6.75 \mathrm{E}-29$; and $\mathrm{rs} 3790622: \mathrm{OR}=0.38$, $95 \% \mathrm{CI}=0.25-0.58, p=2.40 \mathrm{E}-06)$ that were correlated with decreased PTB risk after the Bonferroni correction.

The effects of interleukin gene (IL4, IL6, IL 10) on tuberculosis were assessed by logistic regression analysis under three genetic models, including dominant, recessive and log-additive models (Table 3). For rs2069837 in IL6, found that the risk of tuberculosis in individuals carrying risk allele $\mathrm{G}$ was 1.88 times in log-additive model $(\mathrm{OR}=$ $1.88,95 \% \mathrm{CI}=1.54-2.30, p=6.83 \mathrm{E}-10)$. For rs 1554286 in $I L 10$, we found that the minor allele " $\mathrm{G}$ " raised the risk of PTB under the log-additive model $(\mathrm{OR}=2.28,95 \% \mathrm{CI}$ $=1.89-2.75, p=1.07 \mathrm{E}-17)$. For rs 1518111 in IL10, under the log-additive model, we found that individuals with risk allele $\mathrm{C}$ had a greater risk of tuberculosis than carrying wild alleles increased by $79 \%(\mathrm{OR}=1.79,95 \% \mathrm{CI}=1.49$ $2.14, p=5.04 \mathrm{E}-10)$. For rs3021094 in IL10, we found that the minor allele " $G$ " protect the risk of tuberculosis in the log-additive model $(\mathrm{OR}=0.34,95 \% \mathrm{CI}=0.28-0.42, p=$ 3.31E-24).

For the rs3790622 loci, the specific results showed that the risk of pulmonary tuberculosis in individuals with AA-AG genotype was $63 \%$ lower than that of wild type individuals under dominant genetic model $(\mathrm{OR}=0.37$, $95 \%$ CI $=0.24-0.57, p=6.44 \mathrm{E}-06$ ). Similarly, we also found that the risks of tuberculosis in individuals with $I L 10$ rs3024490 C allele, rs1800872 G allele and rs1800871 G allele were 1.81 times, 1.81 times and 1.81 times than the individuals with wild type (rs3024490: $\mathrm{OR}=1.81,95 \% \mathrm{CI}$ $=1.50-2.17, p=3.75 \mathrm{E}-10 ; \mathrm{rs} 1800872: \mathrm{OR}=1.81,95 \% \mathrm{CI}$ 
Table 3: Association between $I L$ gene polymorphism and PTB risk

\begin{tabular}{|c|c|c|c|c|c|c|}
\hline SNP_ID & Model & Genotype & Control & Case & OR $(95 \%$ CI $)$ & $p$-value \\
\hline \multirow{5}{*}{ rs2069837 } & \multirow{2}{*}{ Dominant } & $\mathrm{A} / \mathrm{A}$ & $312(62.03 \%)$ & $211(45.28 \%)$ & 1 & \multirow{2}{*}{$1.98 \mathrm{E}-07^{*}$} \\
\hline & & $\mathrm{G} / \mathrm{G}-\mathrm{G} / \mathrm{A}$ & 191 (37.97\%) & $255(54.72 \%)$ & $1.97(1.53-2.55)$ & \\
\hline & \multirow{2}{*}{ Recessive } & $\mathrm{G} / \mathrm{A}-\mathrm{A} / \mathrm{A}$ & $480(95.43 \%)$ & $399(85.62 \%)$ & 1 & \multirow{2}{*}{$5.84 \mathrm{E}-07^{*}$} \\
\hline & & $\mathrm{G} / \mathrm{G}$ & $23(4.57 \%)$ & $67(14.38 \%)$ & $3.50(2.14-5.73)$ & \\
\hline & Log-additive & --- & --- & --- & $1.88(1.54-2.30)$ & $6.83 \mathrm{E}-10^{*}$ \\
\hline \multirow{5}{*}{ rs1554286 } & \multirow{2}{*}{ Dominant } & $\mathrm{A} / \mathrm{A}$ & $230(45.73 \%)$ & $104(22.27 \%)$ & 1 & \multirow{2}{*}{$4.18 \mathrm{E}-14$} \\
\hline & & G/G-G/A & $273(54.27 \%)$ & $363(77.73 \%)$ & $2.94(2.22-3.89)$ & \\
\hline & \multirow{2}{*}{ Recessive } & $\mathrm{G} / \mathrm{A}-\mathrm{A} / \mathrm{A}$ & $444(88.27 \%)$ & $330(70.66 \%)$ & 1 & \multirow{2}{*}{$3.38 \mathrm{E}-11$} \\
\hline & & $\mathrm{G} / \mathrm{G}$ & $59(11.73 \%)$ & $137(29.34 \%)$ & $3.12(2.23-4.38)$ & \\
\hline & Log-additive & --- & --- & --- & $2.28(1.89-2.75)$ & $1.07 \mathrm{E}-17^{*}$ \\
\hline \multirow{5}{*}{ rs 1518111} & \multirow{2}{*}{ Dominant } & $\mathrm{T} / \mathrm{T}$ & $234(46.61 \%)$ & $135(28.91 \%)$ & 1 & \multirow{2}{*}{$1.80 \mathrm{E}-08^{*}$} \\
\hline & & $\mathrm{C} / \mathrm{C}-\mathrm{C} / \mathrm{T}$ & $268(53.39 \%)$ & $332(71.09 \%)$ & $2.15(1.65-2.82)$ & \\
\hline & \multirow{2}{*}{ Recessive } & $\mathrm{C} / \mathrm{T}-\mathrm{T} / \mathrm{T}$ & 441 (87.85\%) & $357(76.45 \%)$ & 1 & \multirow{2}{*}{$4.60 \mathrm{E}-06^{*}$} \\
\hline & & $\mathrm{C} / \mathrm{C}$ & $61(12.15 \%)$ & $110(23.55 \%)$ & $2.23(1.58-3.14)$ & \\
\hline & Log-additive & --- & --- & --- & $1.79(1.49-2.14)$ & $5.04 \mathrm{E}-10^{*}$ \\
\hline \multirow{5}{*}{ rs3021094 } & \multirow{2}{*}{ Dominant } & $\mathrm{T} / \mathrm{T}$ & $156(31.01 \%)$ & $287(61.59 \%)$ & 1 & \multirow{2}{*}{$6.38 \mathrm{E}-21^{*}$} \\
\hline & & G/G-G/T & 347 (68.99\%) & $179(38.41 \%)$ & $0.28(0.22-0.37)$ & \\
\hline & \multirow{2}{*}{ Recessive } & G/T-T/T & $390(77.53 \%)$ & $443(95.06 \%)$ & 1 & \multirow{2}{*}{$6.38 \mathrm{E}-13^{*}$} \\
\hline & & $\mathrm{G} / \mathrm{G}$ & $113(22.47 \%)$ & $23(4.94 \%)$ & $0.18(0.11-0.29)$ & \\
\hline & Log-additive & --- & --- & --- & $0.34(0.28-0.42)$ & $3.31 \mathrm{E}-24^{*}$ \\
\hline \multirow{5}{*}{ rs3790622 } & \multirow{2}{*}{ Dominant } & $\mathrm{G} / \mathrm{G}$ & $420(83.50 \%)$ & $435(93.15 \%)$ & 1 & \multirow{2}{*}{$6.44 \mathrm{E}-06^{*}$} \\
\hline & & $\mathrm{A} / \mathrm{A}-\mathrm{A} / \mathrm{G}$ & $83(16.50 \%)$ & $32(6.86 \%)$ & $0.37(0.24-0.57)$ & \\
\hline & \multirow{2}{*}{ Recessive } & $\mathrm{A} / \mathrm{G}-\mathrm{G} / \mathrm{G}$ & $500(99.40 \%)$ & $467(100 \%)$ & 1 & \multirow{2}{*}{0.999} \\
\hline & & $\mathrm{A} / \mathrm{A}$ & $3(0.6 \%)$ & $0(0 \%)$ & - & \\
\hline & Log-additive & --- & --- & --- & $0.37(0.24-0.57)$ & 4.60E- $-06^{*}$ \\
\hline & Dominant & $\mathrm{A} / \mathrm{A}$ & $235(46.72 \%)$ & $134(28.69 \%)$ & 1 & Q Q $1 \mathrm{~F}, 00^{*}$ \\
\hline & Domminalt & $\mathrm{C} / \mathrm{C}-\mathrm{C} / \mathrm{A}$ & $268(53.28 \%)$ & $333(71.31 \%)$ & $2.18(1.67-2.84)$ & $9.01 \mathrm{~L}-09$ \\
\hline rs3024490 & Dosogrivi & $\mathrm{C} / \mathrm{A}-\mathrm{A} / \mathrm{A}$ & $445(88.47 \%)$ & $362(77.52 \%)$ & 1 & $720500^{*}$ \\
\hline & Recessive & $\mathrm{C} / \mathrm{C}$ & $58(11.53 \%)$ & $105(22.48 \%)$ & $2.23(1.57-3.16)$ & $7.20 \mathrm{E}-06$ \\
\hline & Log-additive & -- & --- & -- & $1.81(1.50-2.17)$ & $3.75 \mathrm{E}-10^{*}$ \\
\hline & Dominant & $\mathrm{T} / \mathrm{T}$ & $235(46.81 \%)$ & $134(28.69 \%)$ & 1 & $845 \mathrm{~F}_{-}-0 \mathrm{O}^{*}$ \\
\hline & & G/G-G/T & $267(53.19 \%)$ & $333(71.31 \%)$ & $2.19(1.68-2.88)$ & $8.45 \mathrm{E}-09$ \\
\hline rs1800872 & Pececcive & $\mathrm{G} / \mathrm{T}-\mathrm{T} / \mathrm{T}$ & $444(88.45 \%)$ & $362(77.52 \%)$ & 1 & $765 \mathrm{~F} 06^{*}$ \\
\hline & Recessive & $\mathrm{G} / \mathrm{G}$ & $58(11.55 \%)$ & $105(22.48 \%)$ & $2.22(1.57-3.15)$ & $1.05 \mathrm{E}-06$ \\
\hline & Log-additive & --- & --- & --- & $1.81(1.50-2.17)$ & $3.54 \mathrm{E}-10^{*}$ \\
\hline & Dominant & $\mathrm{A} / \mathrm{A}$ & $235(46.72 \%)$ & $134(28.69 \%)$ & 1 & $981 \mathrm{~F}_{-} 09^{*}$ \\
\hline & Dominant & $\mathrm{G} / \mathrm{G}-\mathrm{G} / \mathrm{A}$ & $268(53.28 \%)$ & $333(71.31 \%)$ & $2.18(1.67-2.84)$ & \\
\hline rs1800871 & Poseccive & $\mathrm{G} / \mathrm{A}-\mathrm{A} / \mathrm{A}$ & $445(88.47 \%)$ & $362(77.52 \%)$ & 1 & 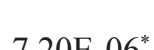 \\
\hline & Recessive & $\mathrm{G} / \mathrm{G}$ & $58(11.53 \%)$ & $105(22.48 \%)$ & $2.23(1.57-3.16)$ & $1.20 \mathrm{E}-06$ \\
\hline & Log-additive & --- & --- & --- & $1.81(1.50-2.17)$ & $3.75 \mathrm{E}-10^{*}$ \\
\hline
\end{tabular}

SNP: single-nucleotide polymorphism; ORs: odds ratio; CI: confidence interval.

${ }^{*} p<0.05$ indicates statistical significance. 
$=1.50-2.17, p=3.54 \mathrm{E}-10 ; \mathrm{rs} 1800871: \mathrm{OR}=1.81,95 \% \mathrm{CI}$

$=1.50-2.17, p=3.75 \mathrm{E}-10$ ).

In this research, we used SHEsis software platform to do haplotype analysis. In our result, a block in IL4 was constructed by rs2070874, rs2227282, rs2243267, rs2243268, rs2243270, rs2243288, and rs2243290 in chromosome 5 with $\mathrm{D}^{\prime}>0.8$, among them the $\mathrm{D}^{\prime}$ of rs2243267 and rs2243268, rs2243267 and rs2243270, rs2243268 and rs2243270, rs2243267 and rs2243290, rs 2243268 and rs2243290, rs2243270 and rs2243290, and rs2243288 and rs2243290 was 1, respectively (Figure 1). A block in IL10 constructed by rs1554286, rs1518111, rs3021094, rs3790622, rs3024490, rs 1800872 , and rs1800871 in chromosome 1 with D' $>0.8$, among them the D' of rs 1554286 and rs 1518111 was 0.98 , the D' of the other loci reach 1 (Figure 2). Association analyses between the three blocks and risk of PTB were performed (Table 4). In IL4, the haplotype " $\mathrm{T}_{\mathrm{rs} 2070874} \mathrm{C}_{\mathrm{rs} 22227282} \mathrm{C}_{\mathrm{rs} 2243267} \mathrm{C}_{\mathrm{rs} 2243268} \mathrm{G}_{\mathrm{rs} 2243270} \mathrm{G}_{\mathrm{rs} 2243288} \mathrm{~A}_{\mathrm{rs} 2243290}$ "

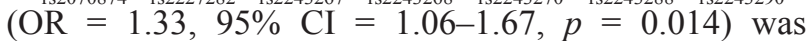
associated with increased PTB risk. The haplotype " $\mathrm{C}_{\mathrm{rs} 2070874} \mathrm{C}_{\mathrm{rs} 22227282} \mathrm{G}_{\mathrm{rs} 2243267} \mathrm{~A}_{\mathrm{rs} 22432268} \mathrm{~A}_{\mathrm{rs} 2243270} \mathrm{~A}_{\mathrm{rs} 2243288} \mathrm{C}_{\mathrm{rs} 22432290}$ " was associated with decreased PTB risk (OR $=0.64$, $95 \% \mathrm{CI}=0.41-1.00, p<0.049)$. In IL10, the haplotypes " $\mathrm{G}_{\mathrm{rs} 1554286} \mathrm{~T}_{\mathrm{rs} 151811} \mathrm{~T}_{\mathrm{rs} 3021094} \mathrm{G}_{\mathrm{rs} 3790622} \mathrm{~A}_{\mathrm{rr} 3024490} \mathrm{~T}_{\mathrm{rs} 1800872} \mathrm{~A}_{\mathrm{rr} 1800871}$ " $(\mathrm{OR}=11.51,95 \% \mathrm{CI}=4.94-26.86, p=1.56 \mathrm{E}-08)$ and
“ $\mathrm{G}_{\mathrm{rs} 1554286} \mathrm{C}_{\mathrm{rs} 151811} \mathrm{~T}_{\mathrm{rs} 3021094} \mathrm{G}_{\mathrm{rs} 3790622} \mathrm{C}_{\mathrm{rs} 3024490} \mathrm{G}_{\mathrm{rs} 1800872} \mathrm{G}_{\mathrm{rs} 1800871}$ " $(\mathrm{OR}=1.80,95 \% \mathrm{CI}=1.50-2.17, p=3.97 \mathrm{E}-10)$ were associated with increased PTB risk. The haplotypes “A $\mathrm{A}_{\mathrm{rs} 1554286} \mathrm{~T}_{\mathrm{rr} 151811} \mathrm{G}_{\mathrm{rs} 3021094} \mathrm{G}_{\mathrm{rs} 3790622} \mathrm{~A}_{\mathrm{rs} 3024490} \mathrm{~T}_{\mathrm{rr} 1800872} \mathrm{~A}_{\mathrm{rs} 1800871}$ " $(\mathrm{OR}=0.39,95 \% \mathrm{CI}=0.31-0.48, p=6.97 \mathrm{E}-18)$ and “A $\mathrm{A}_{\mathrm{rs} 1554286} \mathrm{~T}_{\mathrm{rs} 151811} \mathrm{G}_{\mathrm{rs} 3021094} \mathrm{~A}_{\mathrm{rs} 3790622} \mathrm{~A}_{\mathrm{rs} 3024490} \mathrm{~T}_{\mathrm{rs} 1800872} \mathrm{~A}_{\mathrm{rs} 1800871}$ " $(\mathrm{OR}=0.37,95 \% \mathrm{CI}=0.24-0.57, p=4.84 \mathrm{E}-06)$ were associated with decreased PTB risk.

\section{DISCUSSION}

In this study, we investigated the association between $I L$ polymorphisms and PTB risk in a Tibetan Chinese population. We found one SNP in IL6 and five SNPs in IL10 that were associated with increased PTB risk: rs2069837 $(\mathrm{A}>\mathrm{G}$; OR $=1.95)$, rs1554286 $(\mathrm{A}>\mathrm{G}$; $\mathrm{OR}=2.34), \mathrm{rs} 1518111(\mathrm{~T}>\mathrm{C} ; \mathrm{OR}=1.84), \mathrm{rs} 3024490$ $(\mathrm{A}>\mathrm{C} ; \mathrm{OR}=1.84), \mathrm{rs} 1800872(\mathrm{~T}>\mathrm{G} ; \mathrm{OR}=1.84)$ and rs1800871 $(\mathrm{A}>\mathrm{G}$; OR $=1.84)$, and two SNPs in IL10 that were associated with decreased PTB risk: rs3021094 $(\mathrm{T}>\mathrm{G} ; \mathrm{OR}=0.33)$ and $\mathrm{rs} 3790622(\mathrm{G}>\mathrm{A} ; \mathrm{OR}=0.38)$.

Previous PTB studies investigated the function of host genetic factors and immune response in $M$. tuberculosis (MTB) infection [24]. In humans, macrophages are the main cells involved in intracellular replication of MTB. Macrophages also serve as antigen-presenting cells during

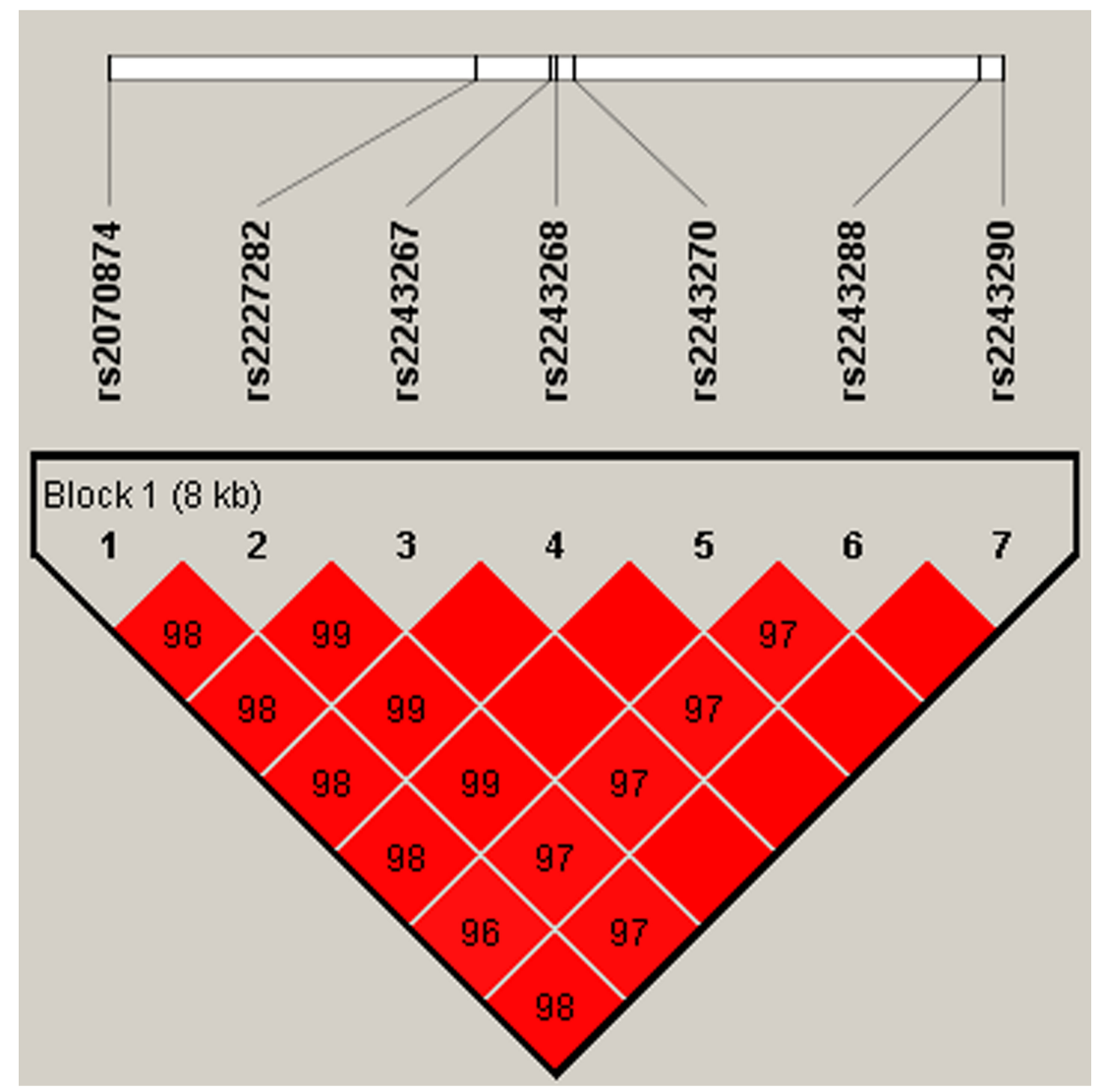

Figure 1: Haplotype block for the SNPs of IL4. A standard color scheme is used to display LD with bright red for very strong LD $\left(\mathrm{LOD}=2, \mathrm{D}^{\prime}=1\right)$. 
Table 4: Haplotype analysis results for $I L$ SNPs

\begin{tabular}{|c|c|c|c|c|c|}
\hline \multirow{2}{*}{ Block ID } & \multirow{2}{*}{ Haplotype } & \multicolumn{2}{|c|}{ Frequency (\%) } & \multirow{2}{*}{ OR $(95 \%$ CI $)$} & \multirow{2}{*}{$p$-value } \\
\hline & & Case & Control & & \\
\hline \multirow{4}{*}{ IL4 } & $\begin{array}{c}\text { rs2070874|rs2227282|rs2243267|rs2243268|rs22432 } \\
70 \mid \text { rs } 2243288 \mid \text { rs } 2243290\end{array}$ & & & & \\
\hline & C G G A A A C & 14.99 & 16.30 & $0.90(0.70-1.16)$ & 0.414 \\
\hline & T C C C G G A & 81.37 & 76.94 & $1.33(1.06-1.67)$ & $0.014^{*}$ \\
\hline & C C G A A A C & 3.32 & 5.17 & $0.64(0.41-1.00)$ & $0.049^{*}$ \\
\hline \multirow{6}{*}{ IL10 } & $\begin{array}{c}\text { rs1554286|rs1518111|rs3021094|rs3790622|rs30244 } \\
90 \mid \text { rs 1800872|rs1800871 }\end{array}$ & & & & \\
\hline & A T G GATA & 18.24 & 37.18 & $0.39(0.31-0.48)$ & $6.79 \mathrm{E}-18^{*}$ \\
\hline & G T T G A T A & 6.65 & 0.60 & $11.51(4.94-26.86)$ & $1.56 \mathrm{E}-08^{*}$ \\
\hline & G C T G C G G & 46.89 & 32.41 & $1.80(1.50-2.17)$ & $3.97 \mathrm{E}-10^{*}$ \\
\hline & A T T GA T A & 24.25 & 20.97 & $1.20(0.97-1.49)$ & 0.087 \\
\hline & A T GAATA & 3.43 & 8.55 & $0.37(0.24-0.57)$ & $4.84 \mathrm{E}-06^{*}$ \\
\hline
\end{tabular}

SNP: single-nucleotide polymorphism; OR: odds ratio; CI: confidence interval. ${ }^{*} p<0.05$ indicates statistical significance.

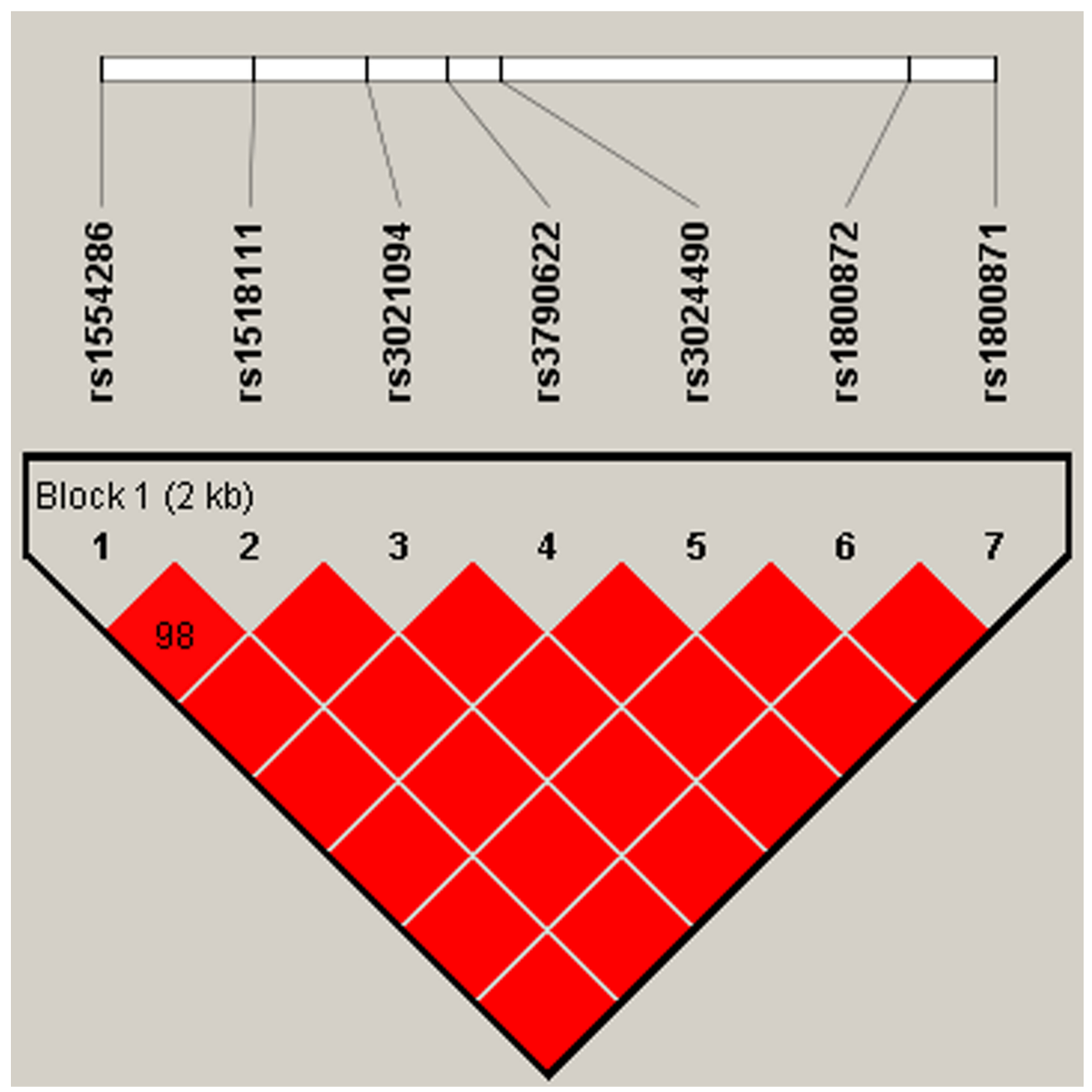

Figure 2: Haplotype block for the SNPs of IL10. A standard color scheme is used to display LD with bright red for very strong LD $\left(\mathrm{LOD}=2, \mathrm{D}^{\prime}=1\right)$. 
the reactivation of lymphocytes, and they function as a vital killer of mycobacteria [25]. Cytokines such as IL6 and IL10 play a key role in driving the appropriate immune response against mycobacteria via activation of inflammatory and immunomodulatory networks orchestrated by both macrophages and T cells [26]. The importance of cytokine IL6 has been studied in previous studies demonstrating that IL6 is important for optimal T-cell development [27, 28]. High levels of IL6 are produced in response to MTB infection and IL6 is critical when bacterial burden is high [19, 29, 30]. A study done in a Southern Brazilian population found that the minor allele "C" of rs1800795 in IL6 decreased the risk of PTB development $(\mathrm{OR}=0.49$, 95\% CI: $0.31-0.78, p=0.008$ ) [12].

Interestingly, more recent meta-analysis studies of rs1800896 in IL10 revealed conflicting results in an analysis of the European and American population $[21,22]$. Studies in Asian population reported the minor allele "G" of rs1800172 in IL10 was associated with a decreased PTB risk (OR $=0.69,95 \%$ CI: 0.31-0.78, $p<0.01)$ whereas no risk association was found in Europeans $(\mathrm{OR}=1.19,95 \% \mathrm{CI}: 0.92-1.54, p=0.18)$, Africans $(\mathrm{OR}=1.01,95 \% \mathrm{CI}: 0.92-1.10, p=0.90)$ [22]. Haplotype analysis found polymorphisms "GCC" constructed by $-1082 \mathrm{G} / \mathrm{A},-592 \mathrm{~A}>\mathrm{C}$ and $-819 \mathrm{C}>\mathrm{T}$ in the IL10 promoter region was in perfect linkage disequilibrium and was associated with an increased PTB risk (GCC vs. others: $p=1.42,95 \% \mathrm{CI}=1.02-1.97$, $p=0.04)$ [21].

IL6 and IL10 are both cytokines that function in the inflammation process. To our knowledge, our study is the first to investigate the association between polymorphic SNPs of three $I L$ genes and PTB risk in a Tibetan Chinese population. Our findings demonstrate an association between polymorphisms in IL6 and IL10 and risk of PTB. We speculate that IL6 and ILIO polymorphisms might modify gene expression and biological function. Polymorphisms of IL6 and IL10 that influence the ability of macrophages to kill $M$. tuberculosis in PTB patients may be a risk factor for PTB. And in the further, we will conduct further validation and disease prediction studies.

\section{MATERIALS AND METHODS}

\section{Ethics statement}

Our present study strictly followed the principles of the Declaration of Helsinki of the World Medical Association and was approved by the Ethics Committee of School of Medicine, Xizang Minzu University. Informed consent forms were signed by all participants.

\section{Study participants}

A total of 467 Tibetan PTB patients were recruited from the third Hospital of Tibet Autonomous Region from
October 2012 to September 2013. Patients were diagnosed based on the criteria of sputum smear or culture positive for MTB pathogen, clinical-radiological findings, and histological evidence of PTB. We excluded individuals who were infected with nontuberculous Mycobacterium, treated with immunosuppressants, or exhibited only extrapulmonary tuberculosis without PTB. At the same time, stochastic samples of 503 healthy controls were enlisted from the same geographical origin and were living in the same region as the patients with PTB. The controls had no previous clinical history or laboratory criteria suggestive of PTB infection. All subjects were all Tibetan Chinese living in Lhasa and nearby.

Cases and controls had at least three generations of paternal ancestry in their ethnic. Cases and controls with any of the following conditions were excluded from the study: human immunodeficiency virus (HIV) positive or known to have any autoimmune, chronic inflammatory, or other diseases.

\section{SNP selection}

Through the literature search, we found that interleukin gene is related to the occurrence of tuberculosis, so we selected IL4, IL6, IL10 genes as the study. We combined our previous literature $[13,15,20$, 23, 31, 32] [15, 20, 23, 32-34], selected seven IL4 SNPs, two IL6 SNPs, and seven IL10 SNPs with a minor allele frequency (MAF) above $5 \%$ and $\mathrm{r}^{2}$ greater than 0.8 from the HapMap Chinese Han Beijing population.

\section{Genotyping}

Genomic DNA was extracted from peripheral blood samples using a genomic DNA purification kit (GoldMag, Xi'an, China). We used spectrometry (DU530 UV/VIS spectrophotometer, Beckman Instruments, Fullerton, CA) to measure the DNA concentration. The primers for amplification and extension reactions were designed with Sequenom MassARRAY Assay Design 3.0 Software (Sequenom, San Diego, CA) [33]. We used Sequenom MassARRAY RS1000 to perform the SNP genotyping with the agreement of the manufacturer $[33,35]$, and we used Sequenom Typer 4.0 software for data management and analysis $[33,34]$.

\section{Statistical analysis}

Microsoft Excel (Microsoft, Redmond, WA) and SPSS Statistics (version 17.0, SPSS, Chicago, IL) were used for statistical analyses. All $p$-values were two-tailed, and $p<0.05$ was considered to be statistically significant. SNP genotype frequencies in the case and control groups were calculated by Chi-square tests and the HardyWeinberg equilibrium (HWE) was used to check the genotype frequency of the control group. Unconditional 
logistic regression analysis was used to examine the odds ratios (ORs) and 95\% confidence intervals (CIs) in order to assess the association between SNPs and PTB [35]. Three models (dominant, recessive, log-additive) were used to test the association between SNPs and PTB [36]. Furthermore, Haploview (version 4.2, Broad Institute, Cambridge, MA) and SHEsis software (http:// www.nhgg.org/analysis/) were used to check the linkage disequilibrium (LD), haplotype construction, and genetic association at polymorphism loci. A D' value greater than 0.8 indicated that the related SNPs formed one block [37].

\section{ACKNOWLEDGMENTS AND FUNDING}

This study was supported by the Major Cultivation Project of Xizang Minzu University (No. 12myZP04), the Natural Science Foundation of Xizang (Tibet) Autonomous Region (No.12KJZRYMY10) and the Major Science and Technology Research Projects of Xizang (Tibet) Autonomous Region (2015XZ01G17). We are grateful for all the participants in our study, as this study would not have been a success without them. We also like to thank the clinicians and hospital staff from the third Hospital of Tibet Autonomous Region, who contributed to the samples collection for this study.

\section{CONFLICTS OF INTEREST}

The authors have no conflicts of interest to report.

\section{REFERENCES}

1. Public Health Division. New South Wales Public Health Bulletin -Discussion Paper 2000. N S W Public Health Bull. 2000; 11:1-16.

2. WHO global tuberculosis control report 2010. Summary. Cent Eur J Public Health. 2010; 18:237.

3. Qu HQ, Fisher-Hoch SP, McCormick JB. Knowledge gaining by human genetic studies on tuberculosis susceptibility. J Hum Genet. 2011; 56:177-82. https://doi. org/10.1038/jhg.2010.164.

4. Lykouras D, Sampsonas F, Kaparianos A, Karkoulias K, Tsoukalas G, Spiropoulos K. Human genes in TB infection: their role in immune response. Monaldi Arch Chest Dis. 2008; 69:24-31. https://doi.org/10.4081/monaldi.2008.408.

5. Britton WJ, Fernando SL, Saunders BM, Sluyter R, Wiley JS. The genetic control of susceptibility to Mycobacterium tuberculosis. Novartis Found Symp. 2007; 281:79-89; discussion -92, 208-9.

6. Comstock GW. Tuberculosis in twins: a re-analysis of the Prophit survey. Am Rev Respir Dis. 1978; 117:621-4. https://doi.org/10.1164/arrd.1978.117.4.621.

7. Thye T, Vannberg FO, Wong SH, Owusu-Dabo E, Osei I, Gyapong J, Sirugo G, Sisay-Joof F, Enimil A, Chinbuah MA, Floyd S, Warndorff DK, Sichali L, et al. Genome- wide association analyses identifies a susceptibility locus for tuberculosis on chromosome 18q11.2. Nat Genet. 2010; 42:739-41. https://doi.org/10.1038/ng.639.

8. Thye T, Owusudabo E, Vannberg FO, Crevel RV, Curtis J, Sahiratmadja E, Balabanova Y, Ehmen C, Muntau B, Ruge G. Supplementary Information A novel susceptibility locus for tuberculosis on chromosome $11 \mathrm{p} 13$ downstream the WT1 gene. Nature Genetics. 2012; 44:257-9.

9. Curtis J, Luo Y, Zenner HL, Cuchet-Lourenco D, Wu C, Lo K, Maes M, Alisaac A, Stebbings E, Liu JZ, Kopanitsa L, Ignatyeva O, Balabanova $\mathrm{Y}$, et al. Susceptibility to tuberculosis is associated with variants in the ASAP1 gene encoding a regulator of dendritic cell migration. Nat Genet. 2015; 47:523-7. https://doi.org/10.1038/ng.3248.

10. Ates O, Dolek B, Dalyan L, Musellim B, Ongen G, TopalSarikaya A. The association between BsmI variant of vitamin D receptor gene and susceptibility to tuberculosis. Mol Biol Rep. 2011; 38:2633-6. https://doi.org/10.1007/ s11033-010-0404-8.

11. Bonar A, Chmiela M, Rozalska B. [Level of mannosebinding lectin (MBL) in patients with tuberculosis] [Article in Polish]. Pneumonol Alergol Pol. 2004; 72:201-5.

12. Milano M, Moraes MO, Rodenbusch R, Carvalho CX, Delcroix M, Mousquer G, Laux da Costa L, Unis G, Dalla Costa ER, Rossetti ML. Single Nucleotide Polymorphisms in IL17A and IL6 Are Associated with Decreased Risk for Pulmonary Tuberculosis in Southern Brazilian Population. PLoS One. 2016; 11:e0147814. https://doi.org/10.1371/ journal.pone.0147814.

13. Abhimanyu, Bose $\mathrm{M}$, Jha P; Indian Genome Variation Consortium. Footprints of genetic susceptibility to pulmonary tuberculosis: cytokine gene variants in north Indians. Indian J Med Res. 2012; 135:763-70.

14. Pereira TB, Thomaz EB, Nascimento FR, Santos AP, Batista RL, Bettiol H, Cavalli Rde C, Barbieri MA, Silva AA. Regulatory Cytokine Expression and Preterm Birth: Case-Control Study Nested in a Cohort. PLoS One. 2016; 11:e0158380. https://doi.org/10.1371/journal. pone. 0158380 .

15. Qi H, Sun L, Jin YQ, Shen C, Chu P, Wang SF, Yin QQ, Qi Z, Xu F, Jiao WW, Wu XR, Tian JL, Xiao J, et al. rs2243268 and rs2243274 of Interleukin-4 (IL-4) gene are associated with reduced risk for extrapulmonary and severe tuberculosis in Chinese Han children. Infect Genet Evol. 2014; 23:121-8. https://doi.org/10.1016/j. meegid.2014.01.031.

16. Amirzargar AA, Naroueynejad M, Khosravi F, Dianat SS, Rezaei N, Mytilineos J, Nikbin B. Cytokine single nucleotide polymorphisms in Iranian populations. Eur Cytokine Netw. 2008; 19:104-12. https://doi.org/10.1684/ ecn.2008.0122.

17. Jang S, Uematsu S, Akira S, Salgame P. IL-6 and IL-10 induction from dendritic cells in response to Mycobacterium tuberculosis is predominantly dependent on TLR2-mediated recognition. J Immunol. 2004; 173:3392-7. 
18. Lande R, Giacomini E, Grassi T, Remoli ME, Severa M, Iona E, Miettinen M, Fattorini L, Orefici G, Julkunen I. Infection of human dendritic cells with Mycobacterium tuberculosis induces cytokine and chemokine gene expression that modulates $\mathrm{T}$ cell response. Journal of Immunology. 2001; 166:7033-41.

19. Ladel CH, Blum C, Dreher A, Reifenberg K, Kopf M, Kaufmann SH. Lethal tuberculosis in interleukin-6-deficient mutant mice. Infection \& Immunity. 1997; 65:4843-9.

20. Rong H, Zhang Q, Zhang Z. Host genetic effect on tuberculosis susceptibility in Chinese Uyghur. Frontiers in Laboratory Medicine. 2017; 1:5-10.

21. Gao X, Chen J, Tong Z, Yang G, Yao Y, Xu F, Zhou J. Interleukin-10 promoter gene polymorphisms and susceptibility to tuberculosis: a meta-analysis. PLoS One. 2015; 10:e0127496. https://doi.org/10.1371/journal. pone. 0127496 .

22. Liang B, Guo Y, Li Y, Kong H. Association between IL10 gene polymorphisms and susceptibility of tuberculosis: evidence based on a meta-analysis. PLoS One. 2014; 9:e88448. https://doi.org/10.1371/journal.pone.0088448.

23. Halstrom S, Thomson R, Goullee H, Baltic S, Allcock R, Temple SE, Price P. Susceptibility to non-tuberculous mycobacterial disease is influenced by rs1518111 in IL10. Hum Immunol. 2017; 78:391-3. https://doi.org/10.1016/j. humimm.2017.02.001

24. Kato-Maeda M, Bifani PJ, Kreiswirth BN, Small PM. The nature and consequence of genetic variability within Mycobacterium tuberculosis. J Clin Invest. 2001; 107:5337. https://doi.org/10.1172/jci11426.

25. Chackerian AA, Perera TV, Behar SM. Gamma interferonproducing CD4+ T lymphocytes in the lung correlate with resistance to infection with Mycobacterium tuberculosis. Infect Immun. 2001; 69:2666-74. https://doi.org/10.1128/ IAI.69.4.2666-2674.2001.

26. Torrado E, Cooper AM. IL-17 and Th17 cells in tuberculosis. Cytokine Growth Factor Rev. 2010; 21:45562. https://doi.org/10.1016/j.cytogfr.2010.10.004.

27. Appelberg R, Castro AG, Pedrosa J, Minoprio P. Role of interleukin- 6 in the induction of protective T cells during mycobacterial infections in mice. Immunology. 1994; 82:361-4.

28. Leal IS, Smedegard B, Andersen P, Appelberg R. Interleukin-6 and interleukin-12 participate in induction of a type 1 protective T-cell response during vaccination with a tuberculosis subunit vaccine. Infect Immun. 1999; 67:5747-54.

29. Giacomini E, Iona E, Ferroni L, Miettinen M, Fattorini L, Orefici G, Julkunen I, Coccia EM. Infection of human macrophages and dendritic cells with Mycobacterium tuberculosis induces a differential cytokine gene expression that modulates T cell response. J Immunol. 2001; 166:703341.

30. Indrigo J, Hunter RL Jr, Actor JK. Influence of trehalose 6,6'-dimycolate (TDM) during mycobacterial infection of bone marrow macrophages. Microbiology. 2002; 148:19918. https://doi.org/10.1099/00221287-148-7-1991.

31. Abhimanyu, Mangangcha IR, Jha P, Arora K, Mukerji M, Banavaliker JN, Brahmachari V, Bose M, Indian Genome Variation Consortium. Differential serum cytokine levels are associated with cytokine gene polymorphisms in north Indians with active pulmonary tuberculosis. Infect Genet Evol. 2011; 11:1015-22. https://doi.org/10.1016/j. meegid.2011.03.017.

32. Liang L, Le J. Association of interleukin -10 gene polymorphisms with genetic susceptibility to tuberculosis. China Tuberculosis Association Clinical Committee, China Tuberculosis Association Fundamental Committee Symposium Proceedings. 2008.

33. Gabriel S, Ziaugra L, Tabbaa D. SNP genotyping using the Sequenom MassARRAY iPLEX platform. Curr Protoc Hum Genet. 2009; Chapter 2: Unit 2.12. https://doi. org/10.1002/0471142905.hg0212s60.

34. Thomas RK, Baker AC, Debiasi RM, Winckler W, Laframboise T, Lin WM, Wang M, Feng W, Zander T, MacConaill L, Lee JC, Nicoletti R, Hatton C, et al. Highthroughput oncogene mutation profiling in human cancer. Nat Genet. 2007; 39:347-51. https://doi.org/10.1038/ ng1975.

35. Bland JM, Altman DG. Statistics notes. The odds ratio. BMJ. 2000; 320:1468.

36. Sole X, Guino E, Valls J, Iniesta R, Moreno V. SNPStats: a web tool for the analysis of association studies. Bioinformatics. 2006; 22:1928-9. https://doi.org/10.1093/ bioinformatics/bt1268.

37. Barrett JC, Fry B, Maller J, Daly MJ. Haploview: analysis and visualization of LD and haplotype maps. Bioinformatics. 2005; 21:263-5. https://doi.org/10.1093/ bioinformatics/bth457. 